\title{
Capítulo 2 \\ De la filosofía al pensamiento filosófico. La búsqueda del regreso al pensar original o el desarraigo de la filosofía
}

Cuando la filosofía deviene dogmática ya no permite pensar.

Y pensar es lo fundamental.

Heidegger nos ha invitado a pensar:

dispongámonos a ello.

Un paso podría ser ir al origen, auscultar lo originario.

En los orígenes del pensamiento filosófico se escuchó la sentencia: ¡ has llegado a mi morada!, y aquí estamos. 
No se sabe cómo.

pero nos encontramos, ya de antemano, en la morada del ser, y nos es imposible huir de ella.

¡Has llegado a mi morada!, se escuchó en los orígenes del pensamiento filosófico. No lo escuchó solo Parménides, sino que lo escuchamos cada uno de nosotros al venir a la existencia; no lo escuchamos solo cada uno de nosotros sino todos los seres cuando recibimos el ser: ¡ has llegado a mi morada!

Ahora, estando ya en el ser no podemos excluirnos de él: hemos ganado su libertad, ¡la libertad de ser! Se era esclavo de la nada, había allí una oscuridad infinita, un vacío existencial; ahora somos libres siendo, dimos el paso posible que nos posibilita toda posibilidad: ¡somos!, ¡estamos siendo!

Salimos de la nada, silo ontológico.

Venimos a ser:

¡la libertad de la existencia! 
Solo con la existencia

se accede a la libertad, aunque esta jamás sea total ni absoluta.

Y en esta "libertad" podemos

-al menos nosotros-

pensar.

Ya se nos han señalado

las sendas para pensar: una,

la del sentipensar, que nos aproxima a la verdad,

a lo que es;

otra, indecible e inasible,

que ni se siente ni se piensa,

lo que no puede ser,

lo que no es.

La diosa lo señaló

desde los orígenes

(aunque no faltan los necios),

y su sentencia ha calado

aunque muy lentamente.

Verdadea lo que es

en su verdad indubitable, sentipensante.

¡Es!

Lo posible.

No puede verdadear lo que no es,

no se puede mostrar,

no se puede develar,

no se puede decir,

no accede a posibilidad alguna. 
¿Puedes siquiera pensar

lo que no es?

¡Solo se puede pensar lo que es!

Lo pensado siempre es,

y de ahí la sentencia

tanto antigua como moderna:

es lo mismo pensar y ser.

Con el mero pensamiento

nos es imposible traer a la realidad

todo lo pensado,

pero en cuanto pensado ya

es.

$¿$ No es lo que se piensa

si ya está siendo pensado?

Obviamente que sí.

Lo que es - la realidad-

no es solo lo puesto ante los ojos,

ahí delante,

es, también, lo pensado

tras de los ojos,

e, indudablemente, sí, también:

lo sentipensado

en el alma,

en el corazón,

tanto como la fuerza

del espíritu.

¡Y todo siendo a una!

Lo pensado.

Lo sentipensado.

Lo sufrido.

Lo real. 
Lo objetivo.

¡Todo

a una!

Como es natural, todo está conectado, interconectado: todo con todo:

no se puede obligar

a lo que es

a no estar conectado

con lo que es,

con lo que todavía no es

(pero es posible),

$\mathrm{e}$, inclusive, de alguna manera,

con lo que no es.

Desde el horizonte ontológico

no hay algo que es más que otra cosa,

ni hay algo menos

o con menos ser.

Todo lo que es

es,

ni más ni menos.

Y si ya algo es, entonces todo es;

es decir:

el ser ya está

y no puede no estar,

no puede no ser.

¡Somos!, y

siendo se es,

sin lugar a dudas.

O se es o no se es,

pero ya somos, 
entonces:

(el) ser,

indudablemente.

¿Qué es lo que es?

¿Qué es lo que no es?

He aquí estas preguntas.

Que no son una misma pregunta.

¡Aunque estén interconectadas!

Una cosa es preguntar por lo que es.

Otra, preguntar por lo que no es.

O como ya lo señaló

la diosa de Parménides:

una cosa es el ser

y otra el no ser.

¡Y no se puede preguntar

de la misma manera por ambas!

Pero es necesario preguntar(nos)

en busca de claridad,

para discernir

lo que es y lo que no es:

ser y no ser,

ser y estar,

ser y pensar,

ser y nada.

¿Por qué preguntarse por el ser?

¿Por qué preguntarse?

¿Por qué?

La pregunta.

Es la pregunta.

Es la pregunta por lo que es. 
Siempre.

Devenimos pregunta, $\mathrm{y}$, en principio, no preguntamos por lo que no es, sino que, siempre, preguntamos por lo que es, pensando.

Pensamos la pregunta, la pregunta es pensada, se piensa lo que es y lo que es se siente: no puede ser de otra manera entre los seres humanos.

Se siente lo que se piensa y se piensa lo que se siente: ¡sentipensamos!

Por esto, siendo

se es.

$\mathrm{Y}$ se es siendo.

Y lo que es

es lo que es:

¡el ser!

Ser:

lo que es, siendo.

Lo que es:

(todo) lo que es, la totalidad de lo que es, la totalidad en su unidad de lo que es: ¡ser!

Perfectamente completo y uno lo que es, ¡es!:

¡ser! 
De ahí que la diosa de Parménides

nos sentencie

la perfección del ser.

Lo que es, el ser,

todo él

es,

y no puede haber en él

algo que no es.

El ser siendo es

perfecto;

el ser siendo

es perfecto;

el ser siendo

es su perfección;

es la perfección de lo que es

totalmente.

No es lícito

que lo que está siendo

sea imperfecto.

La perfección

- para los griegos-

está en lo que es,

es decir, en el ser.

¡Ser es perfección!

¿Qué otra cosa habremos de pensar?

¡Lo que es!,

el ser:

ser.

No tendremos, entonces, otra tarea

sino la de pensar (el) ser.

Pero esta tarea, la de pensar

ser, 
la de preguntarse por el ser,

la de hundirse en el sentido de ser,

muchas veces

se nos ha desviado

y nos hemos quedado

pensando los seres

que tienen ser,

que están siendo,

y pensar cada ser

concreto,

es decir: cada ente,

nos aleja de la tarea fundamental.

Para Heidegger, como ya se vio,

pensar el ente es metafísica;

y la historia de la filosofía

es, de todas maneras, historia

de la metafísica;

¿y el ser?

¡Se nos ha olvidado pensar el ser!

¡Volvamos, de nuevo,

a la tarea original!

No se trata de repetir

lo ya dicho

o la ya pensado,

no.

Se trata de volver a la tarea original,

de conducirnos

por la vía que la diosa

condujo a Parménides

pero que -iquién lo creyera! -

la filosofía misma

nos ha hecho desviar. 
De lo que se trata es de

pensar

lo que es,

pensar el ser,

pensar ser,

pensar de manera ontológica

hundiéndonos en el fundamento

o la esencia

de lo que las cosas verdaderamente son.

Ser

verdadea

lo que es.

Un pensar verdadeante

que se muestre en su ser

desde su ser,

y que muestre el ser,

que se muestre ser

siendo:

¡desde su propio ser!,

estando (en lo que es), ahí,

sin perderse,

sin enajenarse,

sin dejar de ser

su más propio ser,

auténtico,

¡ese es el pensar

que nos corresponde!,

¡ese es el pensar

que nos interesa!

Así es como volvemos la mirada

no al origen

sino a nuestro origen,

a nuestras raíces, 
a nuestro suelo.

Y es aquí, en este suelo,

donde nos topamos con un pensador

que se ha hecho semilla

para la tierra americana:

Rodolfo Kusch,

uno de los más originales pensadores

de América Latina.

¿Hay una ontología en la obra

de Rodolfo Kusch?,

¿pensó este filósofo el problema

del ser?

Vayamos a su obra. 
